\title{
Comparison between outcome of Inside-out \& Outside-in mastoidectomy
}

\author{
Md. Afzal Karim¹, Md. Mostafizur Rahman², Fatema Nihar ${ }^{3}$, Ahmmad Taous ${ }^{4}$ Sheikh Mohammad \\ Rafiqul Hossain ${ }^{5}$, Abdul Baten Mollah ${ }^{6}$ \\ Address of Correspondence: \\ 1. Consultant of ENT, Sher e Bangla Medical College, Barisal \\ 2,5. Assistant Professor, Pabna Medical College, Pabna \\ 3. Assistant Surgeon, Bagra Union Subcenter, Munshiganj \\ 4. Associate Professor, Pabna Medical College, Pabna \\ 6. Senior Consultant, General Hospital, Pabna
}

\begin{abstract}
Background: Chronic suppurative otitis media is a disease that is known worldwide and that is more common in developing countries. Many techniques are available for operating the disease.

Objectives: To compare outcome between Inside-out \& Outside-in mastoidectomy.

Methods: A cross-sectional study was conducted to compare outcome between Inside-Out \& Outside-in mastoidectomy. Period of study was from July' 2010 to March, 2012 in the Department of Otolaryngology and Head-Neck Surgery, BSMMU- Dhaka

Result: majority of the patient were found dry mastoid cavity $13(68.42 \%)$ and rest were wet mastoid cavity $6(31.58 \%)$. On the other hand in outside-in mastoidectomy dry mastoid cavity were $80.6 \%$ and wet were $19.4 \%$. In inside-out mastoidectomy, among 8 attic cholesteatoma cases $5(62.50 \%$ ) had gained hearing (average $6.66 \mathrm{~dB}$ ) and $3(37.50 \%$ ) had no gain or loss of hearing (average $3.89 \mathrm{~dB}$ ); among 11 entire mastoid bowl cholesteatoma cases $3(27.27 \%$ ) had gained of hearing (average 6.11dB) and $8(72.73 \%)$ had no gain or loss of hearing (average $6.87 \mathrm{~dB}$ )
\end{abstract}

\section{Introduction}

Chronic suppurative otitis media is a disease that is known worldwide and that is more common in developing countries. Higher incidence of CSOM with cholesteatoma has been attributed in developing countries due to poor living condition, overcrowding, poor personal hygiene, lack of breast feeding, passive smoking, poor general health, poor resistance to infection, lack of health awareness, paucity of accessible health care, illiteracy \& ignorance. Poverty is a major risk factor in developing countries \& certain neglected population $^{1}$

CSOM is a common condition, affecting $0.5-30 \%$ of any community. The prevalence of squamous type of COM is $3.5 \%$ in Nepal. Now a days, prevalence of CSOM is less than $1 \%$ in USA \& $\mathrm{UK}^{2}$

One study in two selected slum dwellers in Dhaka city shows the prevalence of CSOM is $7.39 \%$ and cholesteatoma is $6.7 \%$ (Kamal et al. 
2004). The prevalence of CSOM in Bangladesh is $4.5 \%{ }^{3}$.

In a prevalence study, it was shown that $5 \%$ general populations have chronic otitis media and in this $1.8 \%$ will be active in any time. In clinical practice up to $50 \%$ of ears with chronic otitis media will be associated with cholesteatoma ${ }^{4}$.

The approach of surgical treatment in the management of the middle ear cholesteatoma has been the matter under debate for years (Sade 2000 and Chang \& Chen 2000). Various surgical techniques and approaches have been advocated to treat aural cholesteatoma but the controversy over open or closs procedures and Outside-in or Inside-out approaches for cholesteatoma surgery is still far from .

The Inside-out mastoidectomy allows the safe removal of cholesteatoma according to the stage of the disease combining the advantage of canal wall down technique with respect to radicality of cholesteatoma removal and canal wall up technique with respect to functional result with the added advantage of single stage reconstruction ${ }^{6}$

Some studies showed better results in hearing level after Inside-out mastoidectomy where A-B gap $<25 \mathrm{~dB}$ in $38.46 \%$ cases and A-B gap $<30$ $\mathrm{dB}$ in $78 \%$ cases compared with results after Outside-in mastoidectomy where there was no hearing gain ${ }^{7}$.

Inside-out mastoidectomy is better for hearing gain \& prevention of cavity problem though some studies showed almost equal results. The post operative result of a dry ear in a series was $83 \%$ and hearing results in the CWW mastoidectomy patients were superior to the CWD groups ${ }^{8}$.

\section{Aims and Objectives}

1. To compare outcome between Inside-out \& Outside-in mastoidectomy.
2. To assess hearing gain in Inside-out mastoidectomy in comparison to Outside-in mastoidectom

3. To find out the graft take rate.

\section{Methods}

A cross-sectional study was conducted to compare outcome between Inside-Out \& Outside-in mastoidectomy.

A hospital based cross-sectional study was conducted to compare outcome between Insideout \& Outside-in mastoidectomy. Period of study was from July' 2010 to March, 2012 in the Department of Otolaryngology and Head-Neck Surgery, BSMMU- Dhaka, had been used as the source of data collection.

All cases of CSOM with cholesteatoma admitted in BSMMU was treated by Inside-out mastoidectomy \& Outside-in mastoidectomy.

\section{Statistical techniqe:}

A semi-structured questionnaire was developed in English. The questionnaire was developed using the selected variables according to the specific objectives. The questionnaire contained questions related to Socio-demographic and hearing status. A check list section was also developed.

The number of patient having Inside-out mastoidectomy were 19 and Outside-in mastoidectomy were 18. Hearing impairment was assessed by Pure tone audiometry with or without masking. Radiologically X-ray mastoid and CT scan of the ears were done. Microscopic examination was done to confirm otoscopic findings and extension of cholesteatoma was noted. Then data were entered into computer with the help of software SPSS windows version 12. After frequency run, data were cleaned and frequencies were checked. Statistical test used for data analysis was Chi square test\& a level of significance was $95 \%$. Pvalue $<0.05$ was considered as significant. 


\section{Results:}

The analyzed data have been presented in this chapter through tables and appropriate graphs.

Table-I: Distribution of patients by age group $(n=37)$

\begin{tabular}{|c|c|c|c|}
\hline Age group & \multirow[t]{2}{*}{$\begin{array}{c}\text { Frequency }(\mathrm{n}) \\
(\%)\end{array}$} & \multirow[t]{2}{*}{$\begin{array}{c}\text { Inside-out Mastoidectomy } \\
\mathrm{n}(\%)\end{array}$} & \multirow[t]{2}{*}{$\begin{array}{c}\text { Outside-in Mastoidectomy } \\
\mathrm{n}(\%)\end{array}$} \\
\hline (Completed years) & & & \\
\hline $6-15$ years & 11(29.73) & $7(18.02)$ & $4(10.81)$ \\
\hline $16-25$ years & 17 (45.95) & $8(21.62)$ & $9(24.32)$ \\
\hline $26+$ years & $9(24.32)$ & $4(10.81)$ & $5(13.51)$ \\
\hline Total & $37(100)$ & 19 (51.35) & 18 (48.65) \\
\hline \multicolumn{4}{|c|}{ Mean $\Rightarrow \mathrm{SD}=20 \Rightarrow 8.5 ;$ Minimum $=7 ;$ Maximum $=52$} \\
\hline
\end{tabular}

Table-II: Extension of cholesteatoma $(n=37)$

\begin{tabular}{|l|c|c|c|}
\hline Characteristics & $\begin{array}{c}\text { Inside-out } \\
\text { mastoidectomy }\end{array}$ & $\begin{array}{c}\text { Outside-in } \\
\text { mastoidectomy }\end{array}$ & $\begin{array}{c}\text { Total } \\
\mathrm{n}(\%)\end{array}$ \\
\hline $\begin{array}{l}\text { Extension of } \\
\text { Cholesteatom }\end{array}$ & $\begin{array}{c}\text { Frquency } \\
(\mathrm{n}=19)\end{array}$ & $\begin{array}{c}\text { Frquency } \\
(\mathrm{n}=18)\end{array}$ & \multirow{2}{*}{$14(37.84 \%)$} \\
\hline Attic & 8 & 6 & $23(62.16 \%)$ \\
\hline Entire mastoid bowl & 11 & 12 & $37(100 \%)$ \\
\hline Total & 19 & 18 & \\
\hline
\end{tabular}

Table shows that cholesteatoma was limited in attic region were $14(37.84 \%)$ and extended into the entire mastoid bowl were 23(62.16\%). 
Table -III: Distribution of patients by different type of surgery $(n=37)$

\begin{tabular}{|l|c|c|}
\hline Type of surgery & $\begin{array}{c}\text { Frequency } \\
\text { (n) }\end{array}$ & $\begin{array}{c}\text { Percentage } \\
\text { (\%) }\end{array}$ \\
\hline Inside-out mastoidectomy & 19 & 51.35 \\
\hline Outside-in mastoidectomy & 18 & 48.65 \\
\hline Total & 37 & 100 \\
\hline
\end{tabular}

Table shows inside-out mastodectomy was done to more than half of the patients $19(51.35 \%)$ and outside-in mastoidectomy was done to less than half of the patient18 (48.65).

Table -IV: Distribution of patients by post operative condition of mastoid cavity $(n=37)$

\begin{tabular}{|c|c|c|c|c|c|}
\hline \multirow{2}{*}{$\begin{array}{l}\text { Condition of the } \\
\text { mastoid cavity }\end{array}$} & \multicolumn{2}{|c|}{ Approaches of the surgery } & \multirow[b]{2}{*}{$x^{2}$} & \multirow[b]{2}{*}{ df } & \multirow[b]{2}{*}{$\mathbf{P}$} \\
\hline & $\begin{array}{c}\text { Inside-out } \\
\text { mastoidectomy } \\
\text { n (\%) }\end{array}$ & $\begin{array}{c}\text { Outside-in } \\
\text { mastoidectomy } \\
\mathrm{n}(\%)\end{array}$ & & & \\
\hline Dry & $13(68.42 \%)$ & $8(44.44 \%)$ & \multirow{3}{*}{2.27} & \multirow{3}{*}{1} & \multirow{3}{*}{$\begin{array}{c}>0.05 \\
\text { ns }\end{array}$} \\
\hline Wet & $6(31.58 \%)$ & $10(55.56 \%)$ & & & \\
\hline Total & $19(100.0 \%)$ & $18(100.0 \%)$ & & & \\
\hline
\end{tabular}

Table-V: Proportion of patients by graft taken after mastoidectomy $(n=37)$

\begin{tabular}{|l|c|c|c|c|}
\hline $\begin{array}{l}\text { Approach } \\
\text { operation }\end{array}$ & $\begin{array}{c}\text { Extention of } \\
\text { Cholesteatoma }\end{array}$ & $\begin{array}{c}\text { Frequency of } \\
\text { Graft taken }(\mathrm{n} \%)\end{array}$ & $\begin{array}{c}\text { Frequency of } \\
\text { Graft Not taken } \\
(\mathrm{n} \%)\end{array}$ & Total \\
\hline \multirow{2}{*}{$\begin{array}{l}\text { Inside-out } \\
\text { mastoidectomy }\end{array}$} & Attic & $5(26.31 \%)$ & $3(15.79 \%)$ & 8 \\
\cline { 2 - 5 } & EMB & $6(31.58 \%)$ & $5(26.32 \%)$ & 11 \\
\cline { 2 - 5 } & Total & $11(57.89 \%)$ & $8(42.11 \%)$ & $19(100 \%)$ \\
\hline \multirow{2}{*}{$\begin{array}{l}\text { Outside-in } \\
\text { masytoidectomy }\end{array}$} & Attic & $2(11.11 \%)$ & $4(22.22 \%)$ & 6 \\
\cline { 2 - 5 } & EMB & $4(22.22 \%)$ & $8(44.45 \%)$ & 12 \\
\cline { 2 - 5 } & Total & $6(33.33 \%)$ & $12(66.67 \%)$ & $18(100 \%)$ \\
\hline
\end{tabular}




$$
X^{2}=4.64, \quad \mathrm{df}=1, \quad \mathrm{P} \text { value }<0.05
$$

Table VI : Comparative hearing status after mastoidectomy $(n=37)$

\begin{tabular}{|l|c|c|c|c|c|}
\hline \multirow{4}{*}{$\begin{array}{l}\text { Approach } \\
\text { Operation }\end{array}$} & $\begin{array}{c}\text { Extension of } \\
\text { Cholesteatoma }\end{array}$ & \multicolumn{2}{|c|}{$\begin{array}{c}\text { Frequency of hearing } \\
\text { gain }\end{array}$} & \multicolumn{2}{|c|}{ Frequency of hearing loss } \\
\cline { 3 - 6 } & $\mathrm{n}(\%)$ & $\begin{array}{c}\text { Average } \\
\text { gain( } \mathrm{dB})\end{array}$ & $\mathrm{n}(\%)$ & Average loss or no gain (dB) \\
\hline \multirow{3}{*}{$\begin{array}{l}\text { Inside-out } \\
\text { Mastoidectomy }\end{array}$} & Attic(n=8) & $5(62.50)$ & 6.66 & $3(37.50)$ & 3.89 \\
\cline { 2 - 6 } & $\begin{array}{c}\text { Entire Mastoid } \\
\text { Bowl( }(\mathrm{n}=11)\end{array}$ & $3(27.27)$ & 6.11. & $8(72.73)$ & 6.87 \\
\cline { 2 - 6 } & Total(N=19) & 8 & & 11 & 7.92 \\
\hline $\begin{array}{l}\text { Outside-in } \\
\text { Mastoidectomy }\end{array}$ & $\begin{array}{c}\text { Attic(n=6) } \\
\text { Entire Mastoid } \\
\text { Bowl( }(\mathrm{n}=12)\end{array}$ & $2(33.33)$ & 5.00 & $4(66.67)$ & 6.99 \\
\cline { 2 - 6 } & Total(N=18) & 7 & 9.00 & $7(58.33)$ & 11 \\
\hline
\end{tabular}

For Attic: $\quad X^{2}=1.38, \quad \mathrm{df}=1, \quad \mathrm{P}$ value $>0.05$

For EMB: $\quad X^{2}=0.24, \quad d f=1, \quad P$ value $>0.05$

\section{Discusssion}

Chronic suppurative otitis media with cholesteatoma affects a large number of patients in developing countries and is quite common in our country especially in middle age and low socioeconomic groups. In attico-antral variety of chronic suppurative otitis media with cholesteatoma is usually present in middle ear, mastoid antrum and mastoid air cell system which is mainly responsible for different complications ${ }^{9}$.

The goal of surgical management of CSOM with cholesteatoma includes the complete eradication of diseases, restoration of hearing, restoration of normal anatomical configuration and no or less number of recurrences. Prior to 1950 recommended surgery for CSOM with cholesteatoma was radical or modified radical mastoidectomy (MRM). Now a day's canal wall down mastoidectomy with tympanoplasty and ossiculoplasty are widely performed ${ }^{10}$.

In the literature surgical technique debated. Some authors primarily set the objective of a dry ear with a low rate of recurrence. whereas others highlighted on the importance of functional results ${ }^{11}$.

Inside-out technique of mastoidectomy is a solution that meet both objectives as shown by the present results. In this procedure posterior canal wall is progressively drilled of as far as it is affected by the cholesteatoma process giving a good overview to epitympanic space (attic region). The overview basically as good as canal wall down(CWD) mastoidectomy is clearly better than the combine canal wall up (CWU) approach where the cholesteatoma is often difficult to remove from the region of the facial recess $^{12}$.

In this study majority of the patients $17(45.95 \%)$ were of $16-25$ years age group followed by 615 years age group which consist of $11(29.73 \%)$ and rest $9(24.32 \%)$ were of $26+$ years age group. Average age was $20 \pm 8.5(\mathrm{SD})$ and minimum age was 7 years and maximum age was 52 years. Another similar study conducted by Hossain (2009) showed that the age range was from 8 years to 50 years \& the highest 
number of patients (45\%) was of $11-20$ years age group. The average age was 21 years which was almost similar findings with this study. We can conclude that the younger group suffers more as because of cellular mastoid, horizontal position of Eustachian tube, enlarged adenoids and recurrent upper respiratory tract infection which is supported by other studies ${ }^{8}$.

In this study Cholesteatoma was limited in attic region were $14(37.84 \%)$ and extended into the entire mastoid bowl was $23(62.16 \%)$. In a study Cholesteatoma was found to be limited to attic region in $43 \%$ cases and extended into the entire mastoid bowl in $57 \%$ cases which was approximately similar to the present study ${ }^{1,8}$.

In this series the patients who underwent insideout mastoidectomy majority of the patient were found dry mastoid cavity 13(68.42\%) and rest were wet mastoid cavity 6 (31.58\%). Another study done by Niklaus and Rudolf showed that in inside-out mastoidectomy post operative dry cavity was $93 \%$ which was higher than this study. This results was higher possibly their meticulous surgical technique. In another series dry mastoid cavity were $89.7 \%$ and wet mastoid cavity were $10.3 \%$ in inside-out mastoidectomy. On the other hand in outside-in mastoidectomy dry mastoid cavity were $80.6 \%$ and wet were $19.4 \%$ which was almost similar findings with my study ${ }^{13,14}$

In the present series post operative findings after inside-out mastoidectomy, no vertigo and facial nerve paralysis were found. on the other hand, after outside-in mastoidectomy, vertigo and facial nerve paralysis were $2(11.11 \%)$, $1(5.56 \%)$ respectively. In another study vertigo was $19.8 \%$ and facial nerve palsy were $6.6 \%$ cases in out- side in mastoidectomy which was more or less similar findings with my study ${ }^{15}$. Post operative findings after inside-out mastoidectomy, recurrence were $1(5.26 \%)$ but no recurrence was noted in outside-in mastoidectomy. Another study conducted by Niklaus and Rudolf (2008), showed that recurrence was $3 \%$ by senior surgeon and $7 \%$ by chief resident.
In this series patients who underwent inside-out mastoidectomy, graft take were $11(57.89 \%)$ and $8(42.11 \%)$ were not taken . On the other hand, in another study among the patients who underwent out-side in mastoidectomy, graft take were $6(33.33 \%)$ and not taken $12(66.67 \%)$. Statistically these differences were found significant $(\mathrm{P}<.05)^{6,16}$.

Hearing depends on multiple factors and it is therefore difficult to make differentiated assessments on the postoperative hearing improvement. This study showed considerable dependence on the preoperative auditory condition (ABG). This study showed status of hearing of the patients after surgical interventions. In inside-out mastoidectomy, among 8 attic cholesteatoma cases $5(62.50 \%)$ had gained of hearing (average $6.66 \mathrm{~dB}$ ) and $3(37.50 \%)$ had no gain or loss of hearing (average 3.89dB); among 11 entire mastoid bowl cholesteatoma cases $3(27.27 \%)$ had gained of hearing (average $6.11 \mathrm{~dB}$ ) and $8(72.73 \%)$ had no gain or loss of hearing (average $6.87 \mathrm{~dB}$ ). In outside-in mastoidectomy, among 6 attic cholesteatoma cases 2(33.33\%) had gained of hearing (average $5.00 \mathrm{~dB}$ ) and $4(66.6775 \%)$ had no gain or loss of hearing (average $7.92 \mathrm{~dB}$ ), among 12 entire mastoid bowl cholesteatoma cases $5(41.67 \%)$ had gained of hearing (average $9.00 \mathrm{~dB}$ ) and $7(58.33 \%)$ had no gain or loss of hearing (average $6.99 \mathrm{~dB}$ ).This study also showed that average post operative $A B G$ in inside-out mastoidectomy was $28.54 \pm 8.04 \mathrm{~dB}$ in case of attic \& $31.67 \pm 8.79 \mathrm{~dB}$ in case of EMB cholesteatoma. Average post operative $A B G$ in inside-out mastoidectomy was $30.36 \mathrm{~dB}$ in $42.11 \%$ cases and in outside-in mastoidectomy was $30.83 \mathrm{~dB}$ in $38.89 \%$ cases. Another study conducted by Niklaus and Rudolf (2008) showed that post operative $A B G$ was $30 \mathrm{~dB}$ or less in inside-out mastoidectomy was $80 \%$ which was higher than my study because of they reconstructed ossicular chain by incus interposition, tympanostapediopexy, tympanoincudopexy and TORP but we reconstructed ossicular chain by above mentioned procedure except TORP ${ }^{6,18,19}$. 
Finally we can conclude that from the attic region disease can be eradicated completely by inside-out approach along with restoration of good hearing with reconstruction of ossicular chain in the same sitting. We can remove diseases from the attic region by outside-in approach but functionality can be maintained properly which is also time consuming and ossicular chain and posterior canal wall reconstruction cannot be done in the same sitting and there is also cavity problem and more chance of facial nerve injury.

\section{Conclusion}

Hearing gain was more in inside-out approach of mastoidectomy in case of attic cholesteatoma in comparison to outside-in mastoidectomy, although it was not statistically significant. Graft taken rate was significantly higher in inside-out mastoidectomy. Discharging cavity was also less in inside-out mastoidectomy, although it was not statistically significant.

\section{References}

1. Youngs, R, Ludman, $H$ \& Write, $T$ 1998, 'Chronic suppurative otitis media: cholesteatoma', in H Ludman (ed.), Diseases of the ear, $6^{\text {th }}$ edn. Edward Arnold Ltd, London, pp. 386-397.

2. Hosssain, MM, Kundu, SC, Hoque, MR, Shamsuzzaman, AKM, Khan, MK \& Halder KK 2006, 'Extracranial complications of chronic suppurative otitis media: a study of 100 cases', Mymensingh Medical Journal, v. 15, no. 1, pp. 4-9.

3. Taous A, Islam MR, Hossain, MM, Ekramuddaula, AFM \& Islam, MS 2010, 'Comparative study of tubotympanic and atticoantral variety of chronic suppurative otitis media', Bangladesh Journal of Otorhinolaryngology, vol. 16, no. 2, pp. 113119.

4. Shrestha, BL, Bhusal, CL, Bhattari, H 2008, 'Comparison of pre and post operative hearing results in canal wall down mastoidectomy with type-III tympanoplasty', Journal of the Nepal Medical Association, vol. 47, no. 172, pp. 224227.
5. Toner, SG, Smyth, GD 1990, 'Surgical treatment of cholesteatoma: a comparison of three technique', American Journal of Otology, vol. 11, pp. 247-249.

Tos, M, Torben, L 1989, ' Hearing after surgery for cholesteatoma using various techniques', Auris Nasus Larynx, Vol. 16, pp. 61-73.

6. Ballenger, JJ 1985, Diseases of ear, nose, throat, head and neck, $13^{\text {th }}$ edn. Lea \& Febiger, Philadelphia pp. 1136-1142.

7. Reddy, TN, Sunil, ND, Shetty, A \& Maini, S 2001, 'Trascanal atticoaditotomy and transcortical mastoidectomy for cholesteatoma: the farrior-olaizola technique revisited', Annal of Otology, Rhinology \& Laryngology, vol. 110, pp. 739-747.

8. Sade, J 2000, 'Surgical planning of the treatment of cholesteatoma and post operative follow-up', Annal of Otology, Rhinology \& Laryngology, vol. 109, pp. 372378.

9. McKenzie, W, \& Brothwell, D 1967, 'Disease of the ear', in D Brothwell, TS Springfield \& CC Thomas (eds.), Diseases of antiquity, pp. 464473.

10. Vikram, BK, Udayashankar, SG, Naseeruddin, K, Venkatesha, BK, Manjunath, $D$ \& Savantrewwa, IR 2008, 'Complication of primary and secondary acquired cholesteatoma: a prospective comparative study of 62 ears', American Journal of Otolaryngology, Head and Neck Medicine and Surgery, vol. 29, pp. 16.

11. Chang, C \& Chen, M 2000, 'Canal wall down tympanoplasty with mastoidectomy for advanced cholesteatoma', American Journal of Otolaryngology, vol. 29, pp. 270-275.

12. Dolandson, JA \& Duckert, LG 1991, 'Anatomy of the ear', in MM Paparella, DA Shumrick, JL Gluckman \& WL Meyerhaff (eds.), Otolaryngology, 3th edn. WB Saunders, Philadelphia, pp 23-49.

13. Dornhoffer, JL 2004, 'Retrograde mastiodectomy with canal wal reconstruction: a follow up report', Otology \& Neurotology, vol. 25, pp. 653-660.

AW 2004, 'Prevalence of chronic suppurative otitis media among the children living in two selected slums in dhaka city', Bangladesh 
Medical Research Council Bulletin vol. 30, no. 3, pp. 95-104.

14. Kavita, JA \& Medhol, RS 2002, 'A descriptive study of the complication of the chronic suppurative otitis media: february 1999 to january 2000', Belgenum Research and publication, pp. 1-3.

Chowdhury, MA \& Alauddin, M 2002, 'Comparative study between tubotympanic \& atticoantral types of chronic suppurative otitis media', Bangladesh Medical Research Council Bulletin, Vol. 28, no. 1, pp. 36-44.

15. Lasisi, AO 2007, 'Hearing outcome after canal wall down mastoidectomy and wullstein type-III tympanoplasty', East and Central African Journal of Surgery, vol. 12, no. 2, pp. 44-47.

16. Niklaus, $R T$ \& Rudolf, $H$ 2008, 'Inside-out technique cholesteatoma surgery: a retrospective long term analysis of 604 operated cases between 1992 and 2006', Otology and Neurotolgy, V. 30, pp. 59-63.

17. Proctor, $B$ 1991, 'Chronic otitis media and mastoiditis', in MM Paparrella , DA Shumrick, JL Gluckman \& WL Meyerhoff (eds.), Otolaryngology, $3^{\text {rd }}$ edn. W B Saunders Company, Philadelphia, vol. 2, pp. 1361-1375

18. Hossain, D, Uddin, M, Taous, A, salam, KS \& Islam, $R$ 2010, 'Canal wall window tympanomastoidectomy: a review of 84 cases', Bangladesh Journal of Otorhinolaryngology, vol. 16, no. 1, pp. 3-8.

19. William, $P L$, Warwich, $R$, Dyson, $M$ \& Bannister, LH 1989, 'Development of special sense organs: the ears,' in Gray's anatomy, $37^{\text {th }}$ edn. Churchill Livingstone, London, pp. 204206. 